\begin{tabular}{rr} 
çağdaş & Yaratıcı Drama Dergisi 2017, 12(1), 105-116 \\
drama & www.yader.org \\
\hline
\end{tabular}

\title{
Yaratıcı Drama Tekniklerinden Faydalanarak Çocuk Gelişimi Programı Öğrencilerinin Eleştirel Düşünme Düzeylerinin Geliştirilmesine Yönelik Çalışma
}

\author{
Sırma Seda Bapoğlu Dümenci ${ }^{1}$
}

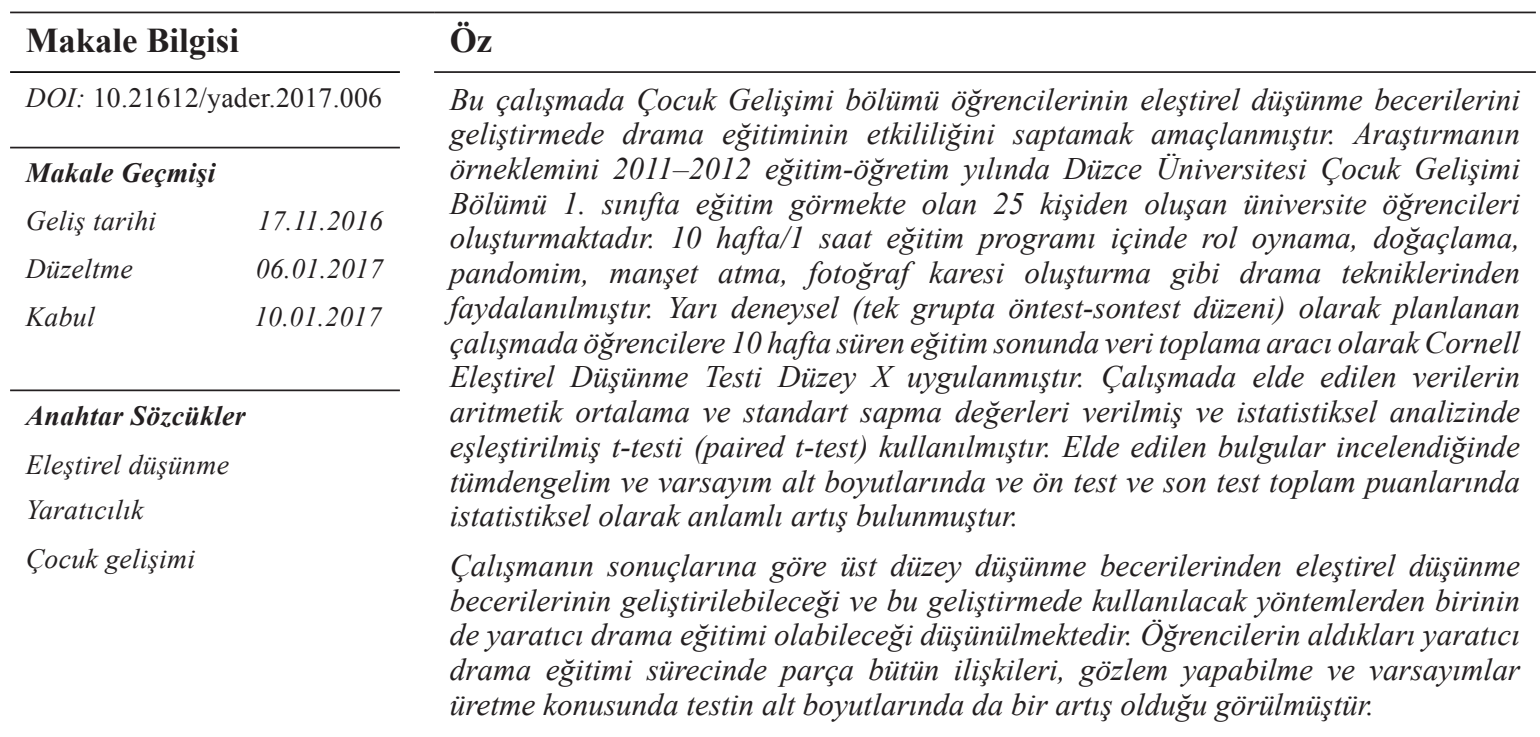

\section{The Research About Development of Critical Thinking Skills Using the Technique of Crreativity Drama Which of Student at Child Development Programme}

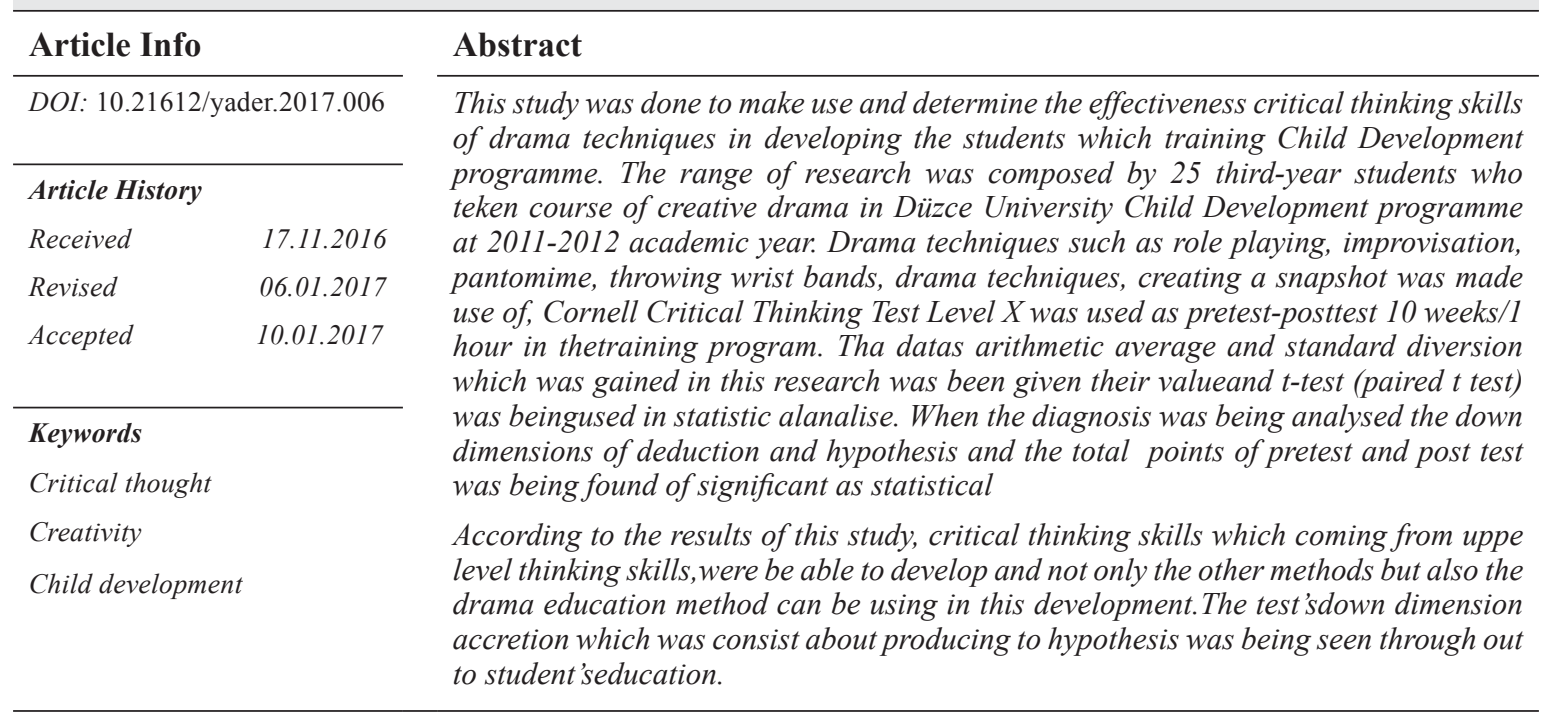

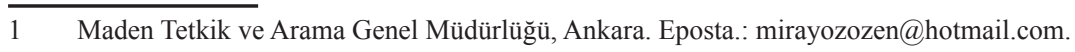




\section{Giriş}

Eğitim, insanlar arasında çevrenin ihtiyaç duyduğu yeni ilişkileri ortaya çıkaran, sorunlara cevap verebilen hayati bir unsurdur. Eğitim sürecinde öğrenilmiş fikirlere bağlı olarak, keşif, yenilenme ve fikirler arası ilişkiler kuracak düşünme becerilerine ihtiyaç duyulmaktadır (Panigrahi,2007). Eğitim, bu süreçte kendi düşüncemizi ve etkileşim halinde olduğumuz kişilerin düşüncelerini göz önünde tutarak kendimizi, çevremizdeki olayları, durumları ve düşünceleri anlamayı amaç edinen aktif ve organize edilmiş zihinsel bir organizasyondur. Eğitim sisteminin öğrencilere potansiyellerini geliştirme firsatı vermesi ve ülke kalkınmasında etkin rol oynayabilmesi için öğretimin içerik ve yöntemleri, eleştirel düşünme, yaratıcı düşünme, bilimsel düşünme, ilişkisel düşünme, akıl yürütme gibi becerileri kazandıracak şekilde yeniden düzenlenmelidir (Özden, 2005).

Nitelikli eğitim, öğrenciyi, verilen program ya da konunun üzerine çıaran, konu hakkında düşündüren, öğrencinin hayal etme gücünü artıran ve yapıcı eleştiriler yapmasını sağlayan öğrenci merkezli bir eğitim sistemidir. Eğitimin temel amacı; bireyin, olaylar ve olaylar arasındaki ilişkileri, kendi kendine disipline etmesidir (Taşkıran, 1994). Bir kişi her hangi bir alana özgü bilgisi çok ise o alana ilişkin çok daha verimli, etkili düşünebilir ve o bilgileri nasıl kullanacağını; düşünme yollarını bilmek şartıyla bunu yapabilir (Kale, 1993). Düşünme anlık meydana gelen bir patlama durumu değil, onu çağrıştıran bazı ortam ve durumlarla ortaya çıkan bir süreçtir (Dewey, 1916). Bilimsel düşünme, eleştirel düşünme, problem çözme, analitik düşünme, tümevarım ve tümdengelim en çok bilinen düşünme becerileri arasında sayılabilir (Günhan ve Başer 2009). Bu düşünme yollarından biri de eleştirel düşünme becerisidir. Eleştirel düşünce yeteneği; kabul etme, reddetme ve muhakeme kuralları çerçevesinde hayata geçirme kabiliyetidir (Ennis, 1959).Eleştirme ise bir şeyi iyi ya da kötü yanlarıyla değerlendirme anlamına gelmektedir (Kaya 1997).

Günümüzde tüm meslek üyeleri gelişmelere ve yeniliklere kolaylıkla uyum sağlayabilmeli, doğru bilgiyi seçebilmeli, yaratıcı düşünceler üretebilmeli, esnek davranabilmeli, kişiliğini geliştirebilmeli, özetle, çağdaş profesyonel nitelikleri kazanmış olmalıdır. Bu niteliklerin kazanılması ise bireylere eleştirel düşünme becerisini kazandırmayı amaçlayan çağdaş eğitim ile mümkündür (Akt. Y1lmaz, 2010).

Ennis'e (1959)'a göre en doğru cevabı bulabilmek ne düzeyde eleştirel düşünebildiğimize bağlıdır (Akt: Akar, 2007).Eleştirel düşünme üzerine pek çok tanım yapılmış, çok defa formüle edilmiş olmasına rağmen evrensel olarak benimsenmiş bir tanımı henüz yapılamamıştır (Dirimeşe, 2006).

Eleştirel düşünmeyi, gözlem ve bilgiye dayanarak sonuçlara ulaşmadır (Paul, 1991). Norris (1985), eleştirel düşünmeyi, öğrencilerin tüm bildiklerini bir konuya uygulayarak kendi düşünme becerilerini değerlendirip davranışlarını değiştirmeleri olarak tanımlamıştır. Beyer (1987)'e göre, eleştirel düşünme, bilginin doğruluğunun, kesinliğinin değerlendirilmesidir ve inançların, argumanların ve bilgi iddialarının bir değeridir. Chance (Akt. Şahinel, (2001) ise eleştirel düşünmeyi, olguları analiz etme, düşünce üretme ve onu örgütleme, görüşleri savunma, karşılaştırmalar yapma, çıkarımlarda bulunma, tartışmaları değerlendirme ve problem çözme yeteneği olarak tanımlamıştır.

Eleştirel düşüme 'kişinin düşünce sistemindeki yapıları usta bir şekilde yöneterek ve bu yapılara entelektüel standartlar getirerek düşünme yönteminin kalitesini arttırdı̆̆ı bir süreçtir (Paul ve Elder, 2005). APA'nın tanımına göre eleştirel düşünme becerileri; yorumları analiz etme, çıkarsama 
yapabilme, kanıtları açıklayabilme ve değerlendirme, kavramsal, metodolojik veya bağlamsal düşünebilme gibi bilişsel becerilerdir (Rapps, 1998). Tüm bu tanımların ortak noktasında eleştirel düşünmenin zihinsel bir süreç olduğuna ve geliştirilebilirliğine dikkat çekilmiştir.

Hiç şüphesiz, düşünme ve eleştirel düşünme eğitimi için en önemli görev okullara ve eğitimcilere düşmektedir. Gelişmiş ülkeler geleneksel öğretmen ve konu merkezli program anlayışına son vermiş, bunun yerine çağdaş ve öğrenci merkezli programlar tasarlayarak uygulamaya koymuşlardır. Son yıllarda benzer çalışmalar ülkemizde de yapılmaktadır. Milli Eğitim Bakanlığı yeni öğretim programlarında köklü değişiklikler yapılması için çalışmalar yapmıştır. Yeni eğitim - öğretim programları davranışçılığın yerine, yapılandırmacılık, çoklu zeka, beyin temelli öğrenme gibi yaklaşımları benimsemiş ve öğretmen merkezli bir anlayış yerine, öğrenci merkezli bir yaklaşıma göre planlanmıştır (MEB, 2005). Dolayısıyla, 2004 yılında yürürlüğe giren son müfredat programında; derslerde, öğrenme alanlarında ve etkinliklerde "eleştirel düşünme" ile ilgili becerilerin gelişmesi amacı da vurgulanmıştır. Ancak; sadece program değişikliğinin bireylere bu becerileri kazandırması beklenemez. Öğrencilerin eleştirel düşünme becerilerini öğrenebilmesi ve kullanabilmesi öğretmenlerin de bu konuda eğitilmiş olmalarıyla ilgilidir (Demirel, 1999).

Eğitim sistemimizde, eleştirel düşünmeyi geliştirmek için yapılan tartışmalar ve yürütülen programlar incelendiğinde eleştirel düşünme öğretiminde dört temel yaklaşım olduğu görülmektedir. Bunlar (Vural \& Kutlu, 2004):

1. Konu Tabanlı Eğitim Yaklaşımı: Glaser (1984) ve McPeck' in de (1981) savundukları bu yaklaşım, öğretilmesi planlanan içerik birimi ile birlikte eleştirel düşünmenin de öğretilmesini öngörmektedir. Bu yaklaşımda eleştirel düşünmenin ilkeleri ve kurallar1 acık bir şekilde, içerik birimine paralel olarak öğrencilere verilmektedir.

2. Konuya Entegre Etme Yaklaşımı: Bu yaklaşım birinci yaklaşıma benzemekle birlikte, içerik birimi ve eleştirel düşünme ilke ve kurallarını bütünleştirmeyi önermektedir. Ancak bu kurallar ve ilkeler açık bir şekilde verilmemektedir.

3. Genel Yaklaşım: Konu tabanlı öğretimden tamamen farklı bicimde yapılandırılmıştır. Eleştirel düşünme becerileri okulda verilen ders içerikleri dışında bir içerik temel alınarak geliştirilen beceri temelli program niteliğindedir. Sternberg \& Bhana (1986), bu yaklaşımın savunucularıdır.

4. Karma Yaklaşım: Ennis (1989) ve Perkins \& Solomon'un (1989) da benimsedikleri bu yaklaşım, hem konu tabanlı yaklaşım hem de genel yaklaşımın birlikte kullanılmasını öngörmektedir.

Eleştirel düşünmenin karmaşık yapısı nedeniyle tek bir yöntem ya da bir ders aracılığıyla kazandırılması elbette ki güçtür. Ancak eleştirel düşünme becerileri eğitim yoluyla geliştirilebilir. Eleştirel düşünmeyi geliştiren birçok model/yöntem vardır ve bu yöntemlerden biri de yaratıcı dramadır (Genç, 2003). Drama; bir sözcüğü, bir kavramı, bir davranış1, bir tümceyi, bir fikri, ya da yaşantıyı ve ya bir olayı, tiyatro tekniklerinden yararlanarak oyun ya da oyunlar geliştirerek canlandırmaktır. Yaratıcı dramanın diğer eğitsel yöntemlere oranla üstünlüğü çok sayıda duyuya aynı anda etki edebilme özelliğidir. En etkili öğrenme ise hem işitsel, hem görsel hem de kinestetik ögeler öğrenme sürecine dahil edildiğinde gerçekleştirilebilir (Akt. Aslan, 2005).

Yaratıcı drama, nerede uygulanırsa uygulansın bir öğrenme yöntemi, kendini ifade etmede bir araç ya da bir sanat biçimi olarak kabul edilebilir. Drama süreçlerinde bir öğrenme, etkileşim 
sağlama ve sosyalleşme ile birlikte, güven kendine saygıyı gelişir. Ayrıca bir topluma ait olma ya da bir grubun üyesi olmanın getirdiği bir güç, iletişim ve problem çözme yetilerinin de geliştirilmesi yaratıcı dramanın önemli boyutlarındandır (Yeğen, 2012).

Günümüz eğitim sistemi içinde, yaratıcı dramanın hedeflerinden bir bölümü; yaratıcılığı geliştirme, estetik gelişimi sağlama, eleştirel düşünme yeteneği kazandırma, birlikte çalışma alışkanlığı kazandırma, sosyal gelişimi sağlama, kendine güven duyma ve karar verme becerilerini geliştirme, dil ve iletişim becerilerini kazandırma, soyut kavramları ya da yaşantıları somutlaştırma, imgelem gücünü, duygularını ve düşüncelerini geliştirme şeklindedir. (Adıgüzel 1993; Üstündağ 1998). Eleştirel düşünme yeteneği kazandırma amacına yönelik beceriler yaratıcı drama etkinliklerinin özellikle doğaçlama ve değerlendirme bölümlerinde yer almaktadır (Adıgüzel, 1993).

$\mathrm{Bu}$ bağlamda, çocuk gelişimi alanındaki bu eksikliğin giderilmesi amaciyla öğrencilere yaratıcı drama dersi verilmektedir. Ancak bu dersin etkililiği halen tartışma konusu olmuş ve eğitim gören üniversite öğrencilerinin çocuk ve drama dersi kapsamında almış oldukları yaratıcı drama eğitiminin, eleştirel düşünme becerilerini olumlu yönde etkileyip etkilemediği henüz netlik kazanmadığ 1 için zorunlu ders müfredatına dahil edilmemiştir. Buradan hareketle verilen bu dersin üniversite öğrencilerinin ileride gelişim desteği sağlayacakları 0-6 yaş çocukların da eleştirel düşünme becerilerini olumlu yönde etkileyebilmesi bu araştırmanın önemini oluşturmaktadır. Araştırma kapsamında yaratıcı drama tekniklerinden faydalanarak çocuk gelişimi programı öğrencilerinin eleştirel düşünme düzeylerinin geliştirilmesi araştırmanın problemini ve bunu etkileyen demografik değişkenler ise araştırmanın alt amaçlarını oluşturmaktadır.

\section{Yöntem}

\section{Araştırmanın Modeli}

Araştırma, öğrencilerin eleştirel düşünme becerilerinin geliştirilmesinde yaratıcı drama eğitiminin etkililiğini anlamaya yönelik yapılan yarı deneysel (tek grupta öntest-sontest düzeni) olarak yapılmıştır.

\section{Çalışma Grubu}

Araştırmanın evren ve örneklemini, Düzce Üniversitesi Sağlık Hizmetleri Meslek Yüksekokulu Çocuk Gelişimi önlisans programında 2011-2012 eğitim-öğretim yılında öğrenim gören birinci sınıf öğrencilerinden "Çocuk ve Drama” dersini alan ve araştırmaya katılmayı kabul eden ve devamsızlık göstermeyen yaş ortalaması 18-19 olan 25 öğrenci oluşturmaktadır. Ayrıca öğrencilerin daha önce drama eğitimi alıp almadığı teyit edilmiş ve drama eğitimi alan bir öğrenci çalışma kapsamına dahil edilmemiştir.

\section{Drama Eğitim Süreci}

Çalışmada öğrencilere 10 hafta/1 saat eğitim programı içinde yaratıcı drama eğitiminin uygulanması içinde 'dramatizasyon, rol oynama, doğaçlama, pandomim, manşet atma, fotoğraf karesi oluşturma, çizim, yarım kalmış materyal' gibi tekniklerinden faydalanılmıştır. Drama etkinliklerini içeren dersler öğrencilerin bağımsız düşünebilmelerine, olaylar arası ilişki kurabilmelerine, yeniden adlandırabilmelerine, varsayımları değerlendirmelerine, varsayımlardan yola çıkarak hipotezleri ortaya koyabilme, bilgiyi aktarabilme ve değerlendirebilme amaçlarına hizmet edecek şekilde yaratıcı 
drama tekniklerinden yararlanılarak düzenlenmiştir. Derste, öğrencilerin öğrenmesini kolaylaştıracak alternatif eğitim yöntemleri sunarak; var olan durumları yeniden sınama, gözden geçirme ve bilgiyi değerlendirip aktarabilme etkinlikleri ile parçadan bütüne, bütünden parçaya ulaşabilme gibi temel düşünme becerileri üzerine kurgulanarak yaratıcı drama tekniklerinden faydalanılmıştır. Uygulanan yaratıcı drama programı; 1sınma- hazırlık, canlandırma ve değerlendirme aşamalarından oluşmaktadır.

Dersler, farklı değişkenlerin etkisini en aza indirmek amacıyla tüm öğrencilere her hafta aynı sınıf ortamında, iki adet çocuk gelişimi ve psikometrik ölçüm uzmanı tarafından aynı süre uygulanmış ve gerekli objektiflik sağlanmaya çalışılmıştır. Ayrıca bitişiklik ilkesi gereği öntest - eğitim program sontest süreçlerinin arasındaki mesafenin dengeli olması ve kontrol bozucu değişkenlerin etkilerinin denetim altına alınması planlanmıştır.

\section{Veri Toplama Aracı}

\section{Cornell Eleştirel Düşünme Testi Düzey X (CEDTDX)}

Araştırmanın verileri öğrencilerin eleştirel düşünme düzeylerini ölçmek için Coşkun Küçüktepe'nin uyarlamasını yaptığı Cornell Eleştirel Düşünme Testi Düzey X kullanılarak toplanmıştır. Cornell Eleştirel Düşünme Testleri Düzey X ve Düzey Z olmak üzere iki ayrı ölçme aracını ihtiva etmektedir. Düzey X, 4-14. sınıflara uygun bir ölçme aracı olup üniversite öğrencilerinin yaşı ile uyumludur. Düzey $Z$ ise yetenekli ortaöğretim öğrencilerine ve lisans ve üzeri gruplara uygundur. CEDTDX herhangi bir kültüre has özellik taşımaması ve ilköğretim 4. sınıftan itibaren uygulanabilir olması nedeniyle araştırmada kullanılması uygun görülmüştür. CEDTDX, Ennis ve Millman (1985) tarafından geliştirilmiş bir ölçme aracıdır. Tüm dünyada ilköğretim düzeyinde eleştirel düşünme becerilerini ölçmede en yaygın olarak kullanılan testin çoktan seçmeli olması, hikâye tarzında hazırlanmış olması ve hesaplanmasının kolay olmasının da etkisiyle CEDTDX olduğu söylenebilir (Kurnaz, 2007).

Test dört boyuttan oluşmaktadır; tümevarımlı akıl yürütme, tümdengelimli akıl yürütme, gözlemlerin ve kaynakların güvenirliğini yargılama ve varsayımları tanımlamadır. CEDTDX toplam 71 maddeden oluşan üç seçenekli çoktan seçmeli bir ölçme aracıdır. Geçerlik ve güvenirlik çalışması için test 96 beşinci sınıf öğrencisine sözel formatta uygulanmış ve elde edilen sonuçların istatistikî analizleri yapılmış testin KR-20 güvenirlik katsayısı 0.79 olarak saptanmıştır. Tümevarım, tümdengelim, gözlem ve varsayım şeklinde 4 alt boyutu bulunan ölçekten alınan puan arttıkça eleştirel düşünme düzeyi de artmaktadır.

\section{Verilerin Analizi}

Araştırmanın problemini yanıtlayabilmek için SPSS veri analizi tekniklerinden faydalanılarak "T testi” kullanılmış, ortalama ve standart sapma değerleri kullanılarak sonuçlar betimlenmiştir. Elde edilen verilerin analizinde aritmetik ortalama, standart sapma ve ilişkisiz örneklemler için p değerleri hesaplanmıştır. İstatistiksel anlamlılık düzeyi $\mathrm{p}<0.05$ olarak alınmıştır. 


\section{Bulgular}

Çalışma grubu öğrencilerine 'Cornell Eleştirel Düşünme Testi Düzey $\mathbf{X}$ ' eğitim öncesi öntest olarak ve belirlenen eğitim süresinin bitiminde ise son-test olarak uygulanmış ve elde edilen veriler, eğitim programı açısından istatistiksel olarak değerlendirilmiştir.

Çocuk Gelişimi programı öğrencilerinin görmüş olduğu 'Çocuk ve Drama' dersinin öğrencilerin CEDTDX'ten aldıkları puanları dolayısıyla eleştirel düşünme becerilerini ne derece etkilediğini tespit etmek amaciyla yapılan araştırmada toplanan verilerden elde edilen bulgular tablolar halinde aşağıda verilmiştir. Bulguları iki bölümde incelenmiştir, bunlar; öğrencilerin CEDTDX'ten aldıkları puanların ortalama puanları ile standart sapma değerlerinin verildiği ve öntest ile sontest arasındaki farkın betimlendiği birinci bölüm ile testin alt boyutları ile öntest sontest arasındaki ilişkiyi gösteren korelasyon değerlerinin verildiği ikinci bölümdür.

Araştırmaya katılan öğrencilerin “Cornell Eleş̧irel Düşünme Testi Düzey X” puanlarının yaratıcı drama etkinliklerinin uygulanmasından sonra etkilenip etkilenmediğini test etmek amacıyla ön-test puanları ile son-test puanları arasındaki farkın önem kontrolü bağımlı T-Testi ile sınanmış ve elde edilen değerler Tablo 1'de verilmiştir.

Tablo 1. Çalışma Grubunu Oluşturan Öğrencilerin CEDTDX Ön-test ve Son-testlerden Aldıkları Puan Ortalamalarının Dă̆ılımı

\begin{tabular}{|c|c|c|c|c|c|}
\hline Testler & $\mathbf{N}$ & $\mathbf{X}$ & $\mathbf{S}$ & $\mathbf{t}$ & I \\
\hline Ön test & 25 & 31.76 & 4,175 & & \\
\hline Son test & 25 & 34,71 & 5,837 & $-10,676$ & $.000 *$ \\
\hline
\end{tabular}

$* \mathrm{p}<.05$

Örneklemde yer alan öğrencilerin yaratıcı drama eğitimi öncesinde eleştirel düşünme düzeyi testi düzey X'ten aldıkları toplam puan ortalamaları ön testte $31.76 \mathrm{iken}$, son testte puan ortalamaları 34.71 çıkmıştır $(\mathrm{p}<.05)$. Anlamlılık düzeyine göre deneme grubu öğrencilerinin CEDTDX ön-test ve son-test puanları arasında anlamlı bir fark olduğu bulunmuştur.

Çalışma grubuna uygulanan $C E D T D X$ ' i oluşturan 4 alt boyutun ön-test ve son-test tüm ölçek puanlarına ilişkin yapılan incelemeler Tablo 2'de sunulmuştur.

Tablo 2. CEDTDX Alt Boyutlarl Ön Test ve Son Test Bulgulart

\begin{tabular}{llll}
\hline $\begin{array}{l}\text { Eleştirel Düşünme Testi } \\
\text { Alt Boyutları }\end{array}$ & Ön Test Ortalama \pm SD & Son Test Ortalama \pm SD & P \\
\hline Tümevarım & $12,20 \pm 2,50$ & $13,68 \pm 3,53$ & 0,080 \\
\hline Tümdengelim & $9,96 \pm 2,57$ & $11,04 \pm 3,41$ & $0,004^{*}$ \\
\hline Gözlem & $10,12 \pm 2,20$ & $10,12 \pm 2,20$ & -- \\
\hline Varsayım & $3,20 \pm 1,55$ & $3,83 \pm 2,10$ & $0,044^{*}$ \\
\hline Toplam & $31,76 \pm 4,17$ & $34,71 \pm 5,83$ & 0,028 \\
\hline
\end{tabular}

Tablo 2 incelendiğinde CEDTDX' in tümevarım alt boyutunda ön test puan ortalamaları 12.20 iken son testte puan ortalamaları 13.68, tümdengelim ön test puan ortalamalar1 9.96 iken, son testte puan ortalamaları 11.04; varsayım ön test puan ortalamaları 3,20 iken son testte puan ortalamaları 
3,83 olarak; gözlem alt boyutunda ise herhangi bir değişikliğin olmadığı bulunmuştur (p değerleri sirasiyla $0.80,0.144,0.144)$. Bu dört faktör içerisinde en fazla madde sayıs1 ve en yüksek varyans değerine sahip olan faktör 2; tümdengelim boyutu olduğu belirlenmiştir.

\section{Tartışma ve Sonuç}

Eğitim programlarının hedefleri arasında olan eleştirel düşünme becerisine yönelik alanyazında yapılan pek çok çalışmada bu becerinin sadece önemi üzerine odaklanılmıştır. Ancak bu beceriyi kazanma ve yaşamda etkili biçimde kullanma boyutu eğitim sistemlerinde halen belirsizliğini korumaktadır. Eleştirel düşünme birçok çalışmada üst düzey düşünme ile eş anlamda kullanılmış, problem çözme, karar verme, eleştirel düşünme ve yaratıcı düşünme gibi alt becerilere yönelik incelemeler üzerine çok fazla yoğunlaşılmamıştır. Bu bağlamda çalışmada eleştirel düşüncenin tümevarım tümdengelim, varsayım, gözlem gibi alt boyutlarında da incelemeler yapılmış ve yaratıcı drama eğitimleri ile olan ilişkisi irdelenerek problemlere çözüm arama yoluna gidilmiştir.

Çalışma sonucunda öğrencilerin yaratıcı drama temelli etkinliklere yönelik dersleri işledikten sonra eleştirel düşünme düzeylerinde anlamlı derecede yükselme görülmüştür. Yaratıcı drama eğitim programın etkililiğini sınamak amacıyla yapılan öntest sontest karşılaştırmalarının yanı sıra grupların sontestleri arasındaki farklılıklarda araştırılmış ve anlamlı farklılık bulunduğu görülmüştür. Bu sonuçlara göre eleştirel düşünme becerilerinin geliştirilmesi için her türlü örgün ve yaygın eğitim kurumunda etkinliklere yer verilmesi gerektiği söylenebilir. Swartz (1989), eleştirel düşünceyi destekleyici nitelikte, kişinin farkındalığını arttırıcı etkinliklerle kişinin düşünme süreçlerini fark etmesini ve bunu planlanmasının önemli bir yeri olduğunu vurgulamaktadır. Benzer şekilde Adıgüzel (1993), Üstündağ (1998), Yeğen (2012) yaptıkları çalışmalarda da yaratıcı dramanın bireylerde yaratıcılığ geliştirme, estetik gelişimi sağlama, eleştirel düşünme yeteneği kazandırma, birlikte çalışma alışkanlığı kazandırma, sosyal gelişimi sağlama, kendine güven duyma ve karar verme becerilerini geliştirme, dil ve iletişim becerilerini kazandırma, soyut kavramları ya da yaşantıları somutlaştırma, imgelem gücünü, duygularını ve düşüncelerini geliştirme gibi hedefleri olduğu belirtilmektedir.

Çalışmada Eleştirel Düşünme Testine ait veriler alt boyutlar açısından incelendiğinde ise 'Tümevarım', 'Tümdengelim', 'Varsayım' alt boyutlarında belirgin yükselmeler görüldüğü, "Gözlem” alt boyutunda ise her hangi bir değişikliğin bulunmadığı görülmüştür.

Benzer şekilde Kale (1994), felsefe aracılığıyla uygulamada ilerleme kaydedilen süreçte, temel aracın tümdengelim akıl yürütme becerileri olduğunu ve bunun kendine özgü bir dünya görüşünün kazanılmasına yardımcı düşünce olduğunu belirtmiştir. Apaydın \& Taş (2010) ve Rapss (1998), tümdengelimsel akıl yürütme süreçlerinin zihinsel aktivitenin başlamasına neden olurken; süreç sonunda yeni bir kavramsal çerçeve yapılandırılmasına da katkı sağladığına dikkat çekmiş ve oluşturulan hipotezlerin test edilmesi ise kuramsal- tümdengelimsel akıl yürütme becerisinin kontrolündeki deneysel süreçlerle gerçekleşir. Yaratıcı drama teknikleri kullanılarak yapılan bir çok çalışmada da dramanın en önemli eğitsel değerinin eleştirel düşünmeyi içermesi olduğu ve eleştirel düşünmenin dramadaki etkinlikler yoluyla geliştirilebileceğini ileri sürülmüştür (Bailin, 1998; Fischer, 2001; Spence \& Campbell 2008; Wilks 1995; Dewey, 1933; Kettula \& Konttas, 2008; Beyer \& Pasnak, 1993). 
Toplumların kalkınmasında, bilgi üretimi ile insanların kendilerini gerçekleştirme sürecinde eleştirel düşünme yetilerinin ve buyetilerin kullanımının önemi büyüktür. Gelişen dünya coğrafyasında eleştirel düşünmenin egemen olmadığı toplumların kalkındığı görülmemiştir. Uygarlığın bir bakıma, yaratıcı fikirlerle ve sorun çözebilme yollarıyla ancak gelişebildikleri bilinmektedir. Bu bağlamda bireylere eleştirel düşünmeyi öğretmek ve bunu derslerin içine entegre etmek birincil amaç olmalıdır. Öğretim yöntemlerinin sorgulandığı, öğrencinin merkeze yerleştirildiği, daha çok katılım, yaratıcılık ve eleştirel düşünme gerektiren çağdaş bir eğitim yöntemi olan 'Yaratıcı Drama' eğitimin her alanında ve eğitimin her kademesinde etkin ve başarılı bir faaliyet olduğu düşünülmektedir. Çalışmaya benzer şekilde yapılan araştırmalarda bireylerin eleştirel düşünme becerilerini geliştirmenin en tekili yollarından birinin yaratıcı dramaya dayalı faaliyetler olduğu bildirilmiştir (Yassa \&Danby, 2007; Facione, P. A., Giancarlo, C. A., Facione, N. C. \& Gainen, J., 1995).

Artar (2004), çalışmasında eleştirel düşünme etkinliklerinin eleştirel düşünme eğilimi ve becerileri üzerindeki etkisini araştırmıştır. Analizlerden elde edilen sonuçlar, deney grubunda eleştirel düşünmeye yönelik olumlu eğilimlerin ortaya çıktığ1 şeklinde yorumlanmıştır. Benzer şekilde Maynard (1996), çalışmasında ikinci sınıftan dördüncü sınıfa kadar eğitimleri süresince öğrencilerin eleştirel düşünme puanlarını incelemiş ve anlamlı bir değişiklik bulamamıştır. Bu bulgular dikkate alındığında eğitim seviyelerinin artmasına rağmen eleştirel düşünme düzeyinin değişmediği sonucu ortaya çıkmaktadır. Buradan hareketle eleştirel düşünme düzeyinde salt eğitimin etkililiğinden ziyade yaratıcı drama temelli eğitimin daha etkili olabileceği söylenebilir. Benzer şekilde Okul Öncesi eğitimi sürecindeki çocuklarla yapılan iki araştırma bu konuda bir düşünce edinilmesine yardımcı olabilir. Araştırmalardan ilki; yaratıcı dramanın kullanıldığı dört ve beş yaşlarındaki çocukların eleştirel düşünme becerilerinin değerlendirilmesi ile ilgilidir. Bu etkinliğin temel amac1; yaratıc1 dramanın bireylerin eleştirel düşünme becerilerini etkileyip etkilemediğini ortaya koymak olmuştur. 'Sonbahar' ve 'Yiyecekler' konusundaki iki üniteyle sürdürülen bir dizi etkinlik sonucunda bu yaş çocuklarında, soru sorma ve sorgulamalarında, bilgi kaynaklarına ulaşma isteğinde önemli derecede farklılıklar bulunmuştur. Diğer bir araştırma ise Simpson'un yaptığı, çocukların, drama yoluyla kazandıkları düşünme becerilerinin okuma yazma ile ilgili boyutu olup olmadığını incelemek konulu araştırmadır. Araştırma çocukların etkin olarak katıldıkları drama çalışmalarının, okuma yazma yeterliklerini geliştirdiğine ortaya koymuştur (Akt. Aslan, 2002). Eleştirel düşünme ve yaratıcılık üzerine yapılan pek çok çalışmada da öğrencilerin analitik düşünme ve metamorfik sorgulama becerilerinin yaratıcılık düzeyini artıran dramatik etkinliklerle artırıldığı bildirilmiştir (Choi \& Kim, 2016; Pringle \& Sowden, 2016; Vass \& Deszpot, 2016).

San (2006), birçalışmasında yaratıı drama temelli eğitim programı ile bireye edilgenlik yerine katılımcı olma, bağımlılık yerine bağımsız olma ve karar verebilme, yetkinleşme, demokratikleşme gibi yetenekler kazandırabileceğini belirtmiştir. Uçan, Taşçı ve Ovayolu (2008), hemşirelik öğrencileri üzerinde yaptıkları çalışmalarda hemşirelerin, karmaşık hasta bakım gereksinimlerini saptayabilmeleri ve sistemik bakım verebilmeleri için eleştirel düşünme güçlerini geliştirmeleri gereken bir takım eğitimler almaları gerektiğini savunmuşlardır.

$\mathrm{Bu}$ bulgular dikkate alındığında yaratıcı drama eğitimi seviyelerinin artmasıyla eleştirel düşünme düzeyinde de artış olduğu sonucu ortaya çıkmaktadır. Buradan hareketle yaratıcı drama yoluyla edinilen bilgilenme, okul disiplinleri içinde edinilen ezbere dayalı, kuramsal bilgilendirme değildir. Yaratıcı dramada bilgi kullanılır ancak dünya içerisinde yer alan öznel ve nesnel ilişkiler içerisinde yapılanır. Bu sebeple yaratıcı drama'nın eğitimde kullanımı eleştirel düşünme yeteneklerinin geliştirilmesi açısından bir gereksinimdir. 
Çocuk Gelişimi bölümü öğrencilerinin eleştirel düşünme becerilerini geliştirmeye yönelik yapılan bu çalışmada da öğrencilerin yaratıcı drama eğitiminden önceki eleştirel düşünme testinden aldıkları puan ortalamalarının $(31,76 \pm 4,17)$ programın sonunda $(41,68 \pm 5,41)$ yükseldiği ve aralarında anlamlı fark bir olduğu bulunmuştur. Bu bağlamda, Çocuk Gelişimi ile benzer eğitim programları ve müfredatı ile ilgili yapılacak iyileştirmenin bu bulguları olumlu yönde değiştireceği düşünülebilir. Sonuç olarak üst düzey düşünme becerilerinden eleştirel düşüncenin geliştirilmesinde yaratıcı drama tekniklerinden faydalanılabileceği düşünülmektedir.

- Çalışmadan elde edilen sonuçlara göre toplumda kişisel/sosyal ve eğitim alanında önemli role sahip olan çocuk gelişimi uzmanlarının yetiştirilmesinde, bu bölümde eğitim alan öğrencilerin eleştirel düşünme becerilerinin yaratıcı drama yöntemi ile geliştirilmesi için sunulacak öneriler şunlardır:

- Yapılan uygulamaların, öğrencilerde özgüvenin gelişmesinde oldukça önemli olmasına dayanarak nitelikli eleştirel yaratıcı drama faaliyetleri yaparak öğrencilerin sınıf içinde ve dışında etkileşim halinde olmaları desteklenmelidir.

- Öğrencilerin eleştirel düşünme becerilerinin geliştirilmesi için yaratıcı drama etkinlikleri amaç değil araç olacak şekilde uygulanmalıdır.

- Öğrencilere sunulan yaratıcı drama etkinlikleri, bilinen, klişe, sonucu tahmin edilen etkinliklerden ziyade eleştirel bakışı sağlayacak, farklı yordama becerileri gerektiren faaliyetler içermelidir.

- Eleştirel düşünme becerilerinin geliştirilmesinde öğrencilere yapılandırılmış yaratıcı drama etkinlikleri yerine yarı yapılandırılmış ya da öğrencinin yapılandırması istenen içerikte uygulamalar sunulmalıdır.

- Yaratıcı drama eğitimlerinin niteliğini ve kalitesini artırmak ve farklı tekniklerden faydalanabilmek için uygulayıcıların içeriğe yönelik çeşitli eğitim ve kurslara katılmaları teşvik edilmelidir.

- Özellikle eleştirel düşünme becerisi geliştirmeyi amaçlayan yaratıcı drama faaliyetleri belli bir zaman diliminde bırakılmamalı mutlaka süreklilik arz etmelidir.

- Çalışmadan elde edilen verilerden yola çıkarak üst düzey becerilerden biri olan ve mantık yürütme, dikkatli muhakeme ve değerlendirme gibi zihinsel aktiviteleri gerektiren eleştirel düşünme becerisinin geliştirilmesinde yaratıcı drama tekniğinin etkili bir yöntem olması sebebiyle yaratıcı drama etkinliklerinin öğrencilerin müfredatlarına dahil edilmesi uygun görülmektedir.

- Eleştirel düşünmenin temelinde; (1) problemleri tanıma, (2) problemlerin çözümü için uygun araçlar bulma, (3) problemlerle ilgili bilgi toplama, (4) ifade edilmeyen varsayımları ve değerleri tanıma; (5) eldeki verileri yorumlama, (6) dili doğru, açık ve net bir şekilde kavrama ve kullanma, (7) kanıtları ve delilleri değerlendirme, (8) önermeler arasındaki mantıksal ilişkileri tanıma, (9) sağlam sonuçlara ve genellemelere ulaşabilme, (10) ulaşılan genelleme ve sonuçları sınama, (11) mevcut görüş ve inançları eldeki tecrübe temelinde yeniden inşa edebilme gibi becerilerin yer alması, araştırmadan elde edilen sonuçlar 1şı̆̆ında eleştirel düşünme odaklı yaratıcı drama etkinliklerinin öğrencilerin ders programlarına dahil edilmesiyle bir çok düşünsel becerinin destekleneceğini ortaya koymaktadır. 
Eleştirel düşüncenin gelişmesinde, erken çocukluk dönemin ile çocuk gelişimi ve eğitimi ile ilgili faaliyetlerin temel ögelerinden biri olan eleştirel düşünme becerisi ne kadar üst düzey ise çocuklara verilen eğitimin ve destekleyici gelişim programlarının kalitesi, etkinliği ve yeterliliği o kadar verimli olacaktır. Üst düzey düşünme becerilerinden eleştirel düşünme becerilerini geliştirmede yaratıcı dramanın sadece çocuklar için değil çocuk gelişimi programı öğrencileri için de etkili bir eğitim yöntemi olduğu söylenebilir. Çocuk gelişimcilerinin eğitiminde öğrencilerin eleştirel düşünme becerisini artıracak eğitim yöntemlerinin uygulanması, eğitiminde yaratıc1 drama tekniklerinden faydalanılması ve müfredat programlarının gözden geçirilerek eleştirel düşünmeyi geliştirecek şekilde düzenlenmesi önerilmektedir. Gelecekte bu yönde hizmet verebilecek çocuk gelişimi uzmanlarının yetiştirilmesinde, eleştirel düşünmeyi geliştiren eğitim içeriklerinin oluşturulması ve eğitim sürecinin bu şekilde yapılandırılması önemlidir.

\section{Kaynakça}

Adıgüzel, H. Ö. (1993). Oyun ve yaratıcı drama ilişkisi. Ankara Üniversitesi Eğitim Bilimleri Enstitüsü, Yayınlanmamış Yüksek Lisans Tezi, Ankara.

Akar, Ü. (2007). Öğretmen adaylarının bilimsel süreç becerileri ve eleştirel düşünme beceri düzeyleri arasındaki iliş̧ki. Afyonkocatepe Üniversitesi, Yayınlanmamış Yüksek Lisans Tezi, Afyonkarahisar.

Aslan N. (2002). İlköğretimde drama ve tiyatro. Oluşum Tiyatrosu ve Drama Atölyesi. s:36.

Bailin, S. (1998). Critical thinking and drama education. Research in Drama Education: The Journal of Applied Theatre and Performance, 3(2), 145-153. Doi: 10.1080/1356978980030202.

Beyer, B. (1987). Practical strategies for the teaching of thinking. Boston: Allyn and Bacon, INC.

Beyer, B. K., Pasnak, R. (1993). Helping children think better: The developmental lesson set approach. Journal of Research and Development in Education, 26, 96-105.

Cengiz, E.G. (2004). Üniversite öğrencilerine yönelik eleştirel düşünme etkinliklerinin eleştirel düşünme eğilimi ve becerileri açısından değerlendirilmesi. Yayınlanmamış Yüksek Lisans Tezi, Ankara Üniversitesi Sosyal Bilimler Enstitüsü, Ankara.

Choi, H.H. \& Kim, M.J. (2016). The effects of analogical and metaphorical reasoning on design thinking. Thinking Skills and Creativity 23, 29-41.

Çıkrıkçı, N. (1992). Watson-Glaser eleştirel akıl yürütme gücü ölçeğinin (form ym) lise öğrencileri üzerindeki ön deneme uygulaması. Ankara Üniversitesi Ĕ̈itim Bilimleri Fakültesi Dergisi, 25(5), 559-569.

Demirel, O. (1999). Plandan değerlendirmeye ögretim sanatı. (4. baskı). Ankara: Pegem Yayınevi

Dewey, J. (1916). Democracy and education. Erişim Tarihi: 12.02.2012. http://www.jstor.org/stable/992653.

Dewey, J. (1933). How we think. A restatement of the relation of reflective thinking to the educative process. Boston: D.C. Heath.

Dirimeşe, E. (2006). Hemşirelerin ve öğrenci hemşirelerin eleştiren düşünme eğilimlerinin incelenmesi. Dokuz Eylül Üniversitesi Sağllk Bilimleri Enstitüsü, Yüksek Lisans Tezi, İzmir.

Ennis, R. (1959). The development of a critical thinking test: University of Illinois: Unpublished Doctoral Dissertation. USA.

Facione, P. A., Giancarlo, C. A., Facione, N. C. \& Gainen, J. (1995). The disposition toward critical thinking. Journal of General Education. 44(1), 1-25.

Genç, N. (2003). Eğitimde yaratıcı dramanın alımlanması. Hacettepe Üniversitesi Eğitim Fakültesi Dergisi, 24,196-205.

Günhan, CB. Başer N. (2009). Probleme dayalı öğrenmenin öğrencilerin eleştirel düşünme becerilerine etkisi. Türk Eğitim Bilimleri Dergisi, 7(2),451-482. 
Yaratıcı Drama Tekniklerinden Faydalanarak Çocuk Gelişimi Programı Öğrencilerinin

Eleştirel Düşünme Düzeylerinin Geliştirilmesine Yönelik Çalışma

Kale, N. (1994). Felsefe öğretimi. Ankara Üniversitesi Yayınları Eğitim Bilimleri Fakültesi Dergisi, 27 (1), 113-120.

Kale, N.(1993). Üç düşünsel yeti: Eleştirel düşünme, yaratıcı düşünme, problem çözme. Yaşadıkça Eğitim Dergisi,28, 24-27.

Kaya, H. (1997). Üniversite öğrenci/erinde eleştirel akıl yürütme gücü. İstanbul Üniversitesi, İstanbul, yayımlanmamış doktora tezi.

Kettula \& Konttas, K. (2008). Aiming at critical thinking: A case of teaching professional ethics through applied drama. 13. Uluslararası Eğitimde Yaratıcı Drama/Tiyatro Kongresi, s.119-128.

Kurnaz, A. (2007). İlköğretim beşinci sınıf sosyal bilgiler dersinde beceri ve içerik temelli eleştirel düşünme becerileri, erişi ve tutumlarına etkisi. Doktora Tezi. Konya: Selçuk Üniversitesi Sosyal Bilimler Enstitüsü.

Maynard, CA. (1996). The relation of critical-thinking abilitiy to profesional nursing competence. Journal of Nursing Education, 35(1), 12-18.

MEB. (2005). İlköğretim 1-5. sınıf programları. Ankara.

Norris, P.S. (1985).Synthesis of research on critical thinking. Educational Leadership, 42(8),40-45.

Özden, Y. (2005). Öğrenme ve öğretme. Ankara: Pegem Yayıncılık.

Panigrahi, L.K (2007). New directions in education. Chandigarh, IND: Global Media .p 1. http://site.ebrary. com/lib/duzce/Doc?id=10416841\&ppg=10

Paul, R.ve Elder, L. (2010). Tiny Critical Thinking guide Concepts and Tools:Minik Eleştirel Düşünme Kılavuzu, Kavramlar ve Araçlar. (t.y.). ( M. B. Fidan, Çev). Erişim: 10.01.2013, http://www.criticalthinking.org/.

Paul, R.W. (1991).Staff development for critical thinking: lesson plan remodelling as the strategy, A.L. Costa (Ed.). Developing Minds:A Reseource Book For Teaching Thinking, Revised Education, Volume1, Alexandria,Virginia:ASCD.

Pringle, A. \& Sowden, P. (2016). The Mode Shifting Index (MSI): A new measure of the creative thinking skill of shifting between associative and analytic thinking. Thinking Skills and Creativity 23, 17-28.

Rapss, J. (1998). Tetsing a theoretical model of critical thinking and cognitive development. University of San Diego. Unpuplished Doctoral Dissertatio.

San, İ. (2006). Eğitimde Yaratıcı Drama. Erişim Tarihi: 10.04.2012 http://yaratici-drama.blogspot.com/2009/05/ egitimde-yaratici-drama.html. s.46-57.

Spence- Campbell, S.M. (2008). Pedagogical change: Using drama to develop the critical imagination. Doctoral Dissertation. University of Alberta, Canada.

Swartz, R. J. (1989). Making good thinking stick: The Role of Metacognition, Extended Practice, and Teacher Modeling in the Teaching of Thinking. D.. M. Topping, D. C. Crowell, \& V. N. Kobayashi (Eds.), Thinking across cultures: The third International Conference on Thinking (pp. 417-436).

Şahinel, S. (2001). Eleştirel düşünme becerileri ile tümleşik dil becerilerinin geliştirilmesi. Doktora Tezi, Hacettepe Üniversitesi Sosyal Bilimler Enstitüsü, Ankara.

Taşkıran, P. (1994). Yaratıcı bireylerin yetiştirilmesi açısından sanat eğitiminin yeri ve önemi. İzmir: D.E.Ü. Eğitim Fakültesi, (Yayımlanmamış Yüksek Lisans Tezi).

Uçan, Ö.,Taşçı, S., Ovayolu, N. (2008). Eleştirel düşünme ve hemşirelik. Fırat Sağllk Hizmetleri Dergisi, 3(7), $17-27$.

Üstündağ, T. (1998). Yaratıcı drama eğitim programının öğeleri. Eğitim ve Bilim, 22(107), 28-35.

Vass, E. \& Deszpot, G. (2016). Introducing experience-centred approaches in music teachereducation-Opportunities for pedagogic metamorphosis. Thinking Skills and Creativity 23, 1-16.

Vural, R.\& Kutlu O. (2004). Eleştirel düşünme: Ölçme araçlarının incelenmesi ve bir güvenirlik çalışması. Çukurova Üniversitesi Sosyal Bilimler Enstitüsü Dergisi, 13(2), 189-199.

Wilks, S. (1995). Critical and creative thinking: Strategies for classroom inquiry. Armidale, NSW: Eleanor Curtain. 
Yassa, N. \& Danby, M. (1997). High school students involvement in creative drama: The effect of social interaction. Abstract of Papers of Researching Drama and Theatre in Education Conference, University of Exeter, 70.

Yeğen, G. (2012). Yaratıcı drama. İlköğretim Online Öğretim Uygulamaları Serisi, 2(2), 1-4.

Yılmaz, E. (2010). Hemşirelik öğrencilerinin eleştirel düşünme düzeyleri ve kitap okuma alışkanlığına ilişkin tutumları. Yüksek Lisans Tezi, Hacettepe Üniversitesi, Ankara. 